\title{
Betale med tid
}

\author{
En legekonsultasjon innebærer ofte lang reise- og ventetid. Tiden koster både pasienten og samfunnet \\ mye penger.
}

Hva koster det en pasient å oppsøke helsevesenet? Svaret avhenger av hva som telles som kostnad. Ett svar er egenandelen, f.eks. 200 kroner. Et annet er at det koster tiden besøket tar: reisetid, ventetid og konsultasjonstid.

En nylig publisert amerikansk beregning (1) viser at det i gjennomsnitt går med 121 minutter til en konsultasjon: 37 minutter til reisetid, 20 minutter til direkte kontakt med legen og 64 minutter til venting, registrering o.l. Forskerne omregnet tidsbruken til penger, basert på inntektstapet den enkelte har ved å bruke tid på annet enn jobb. Gjennomsnittlig egenandel var 32 dollar, mens tidsbruken kostet 43 dollar.

At kostnaden beregnes i forhold til tapt inntekt innebærer bare at det er et rimelig mål på den monetære kostnaden, ikke at det er et mål å være på jobben hele tiden. Vi kan like gjerne si at det som oppgis, er tid brukt på andre aktiviteter - gå en tur, være med venner eller sitte på kontoret og skrive for spalten Legelivet.

\section{Sosiale ulikheter i reise- og ventetid} Kostnaden varierte sterkt med pasientens sosioøkonomiske status. Selv om det ikke var forskjeller i ren konsultasjonstid, betalte en latinamerikansk eller afroamerikansk pasient i gjennomsnitt $25 \%$ mer i reiseog ventetid. Også lavinntektsgrupper og arbeidsløse brukte mer tid enn de bedrestilte.

Selv om dette er amerikanske data er de ikke uinteressante for andre land. Å inkludere reisetid og ventetid i kostnadsberegningen er rimelig, og å undersøke om kostnadene fordeles etter en sosial gradient er nødvendig - for en etterrettelig beskrivelse av sosial ulikhet.

\section{Kostnad for samfunnet}

Én ting er den enkeltes kostnader, en annen er hva tidsbruken samlet koster samfunnet.

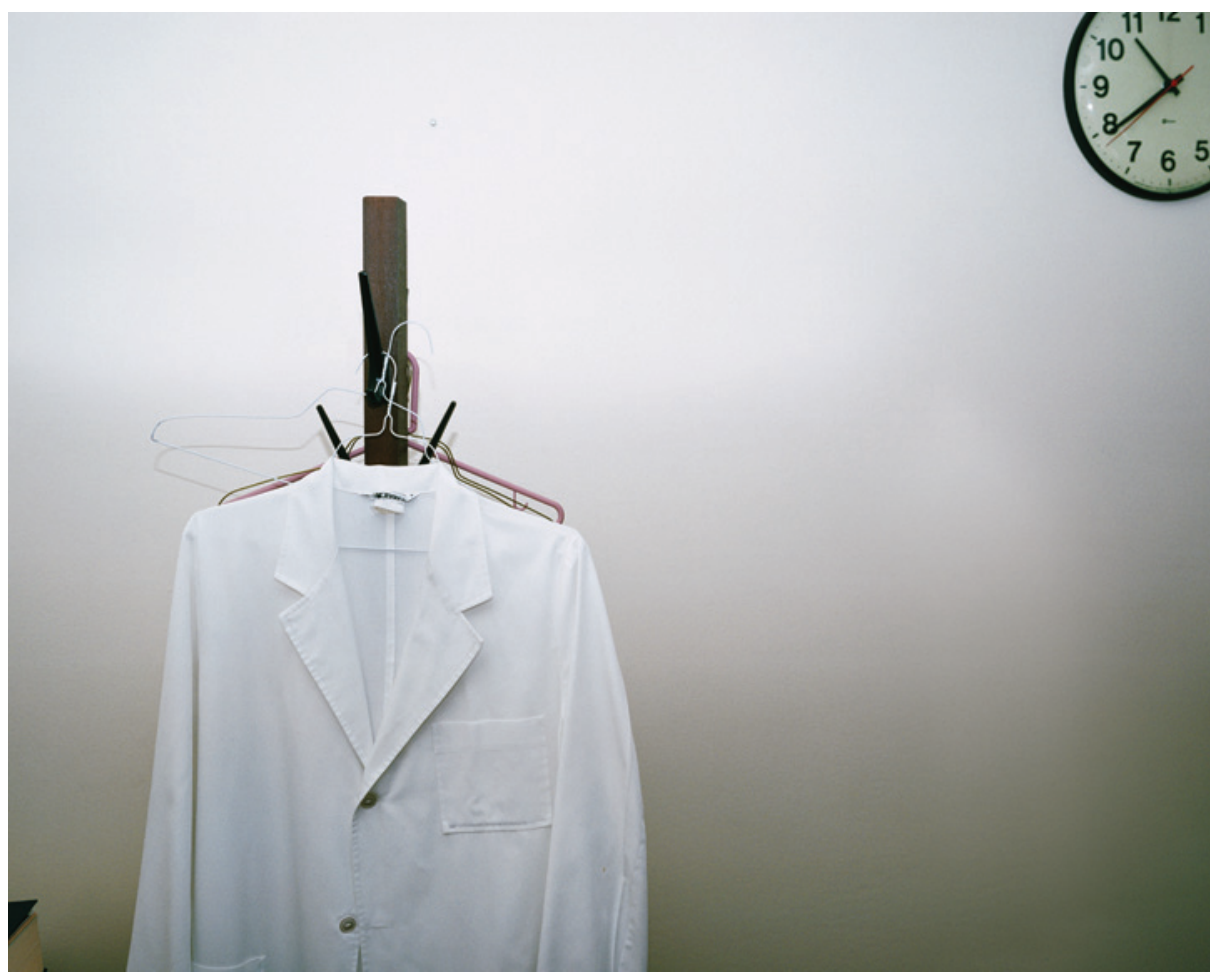

Illustrasjonsfoto: Corbis/NTB scanpix

For USA anslås dette til 52 milliarder dollar årlig. For et inntrykk av hva dette kan være i Norge, kan vi (om tidsbruken er lik) beregne tidskostnaden for fastlegebesøk alene til 19 millioner timer - ikke medregnet selve konsultasjonstiden på 20 minutter. Gjennomsnittlig timelønn i Norge er 280 kroner, og den samlede reise- og ventetidskostnaden kan dermed være opp mot 5 milliarder kroner.

Er det mulig å redusere tidskostnadene? Svaret er ja. Mer effektiv logistikk kan redusere ventetidene. Utvidede helsetilbud der folk er, f.eks. på skoler og ved universiteter, reduserer reisetidene. Ny teknologi kan også utnyttes bedre. Telemedisin og elektronisk kontakt, som Skype og e-post, er bare noen eksempler på hvilke muligheter en fornuftig bruk av den nye teknologien representerer. Dette vil redusere unødvendig tidsbruk og sosial skjevhet.

\section{Berit Bringedal}

LEFO - Legeforskningsinstituttet

\section{Litteratur}

1. Ray KN, Chari AV, Engberg J et al. Disparities in time spent seeking medical care in the United States. JAMA Intern Med 2015. E-publisert 5.10. 2015. 